\title{
Childhood Nongerminomatous Germ Cell Tumor
}

National Cancer Institute

\section{Source}

National Cancer Institute. Childhood Nongerminomatous Germ Cell Tumor. NCI

Thesaurus. Code C123841.

A nongerminomatous germ cell tumor occurring in children. 